\title{
Manufacture and sensory analysis of reduced- and low-sodium Cheddar and Mozzarella cheeses
}

\author{
Balasubramanian Ganesan, ${ }^{1}$ Kelly Brown, David A. Irish, Carl Brothersen, and Donald J. McMahon \\ Dairy Technology and Innovation Laboratory, Western Dairy Center, Department of Nutrition, Dietetics, and Food Sciences, Utah State University, \\ Logan 84322
}

\begin{abstract}
High sodium intake negatively affects consumer health, thus there is active interest in lowering sodium levels in dairy foods. Cheddar and low-moisture, partskim Mozzarella cheeses were made with total salt levels of $0.7,1.0,1.25,1.35$, and $1.8 \%$ (wt/wt) in triplicate, thus reducing sodium by 25 to $60 \%$. Multiple manufacturing protocols for salt reduction were used to produce cheeses with similar postpress moisture and $\mathrm{pH}$, independent of the final salt levels in cheese, in order to study the role of salt in cheese acceptability. Cheese flavor was evaluated by a descriptive taste panel on a 15-point intensity scale. Consumer acceptance was evaluated by a consumer panel on a 9-point hedonic scale. Taste panels conducted with cubed Cheddar cheese (at 3 and $6 \mathrm{mo}$ ) and cold shredded Mozzarella cheese (at $3 \mathrm{wk}$ ) showed that consumer liking for cheese was low at 0.7 and $0.9 \%$ salt, but all cheeses containing higher salt levels $(1.25,1.35$, and $1.8 \%$ salt) were comparably preferred. The cheeses had acceptable liking scores $(\geq 6)$ when served as quesadilla or pizza toppings, and consumers were able to differentiate cheeses at alternate salt levels; for example, 1.8 and $1.5 \%$ salt cheeses scored similarly, as did cheeses with $1.5 \%$ and $1.35 \%$ salt, but $1.35 \%$ salt cheese scored lower than and was discernible from $1.8 \%$ salt cheese. Descriptive panelists perceived salty, sour, umami, bitter, brothy, lactone/fatty acid, and sulfur attributes as different across Mozzarella cheeses, with the perception of each significantly increasing along with salt level. Salty and buttery attributes were perceived more with increasing salt levels of Cheddar cheese by the descriptive panel at 3 mo, whereas bitter, brothy, and umami attributes were perceived less at the higher salt levels. However, this trend reversed at 6 mo, when perception of salty, sour, bitter, buttery, lactone/fatty acid, and umami attributes increased with salt level. We conclude that consumers can distinguish even a $30 \%$ salt reduction
\end{abstract}

Received August 29, 2013.

Accepted December 4, 2013.

${ }^{1}$ Corresponding author: g.balsu@usu.edu and a gradually phased sodium reduction is needed to improve acceptability of lower sodium cheeses.

Key words: Cheddar cheese, Mozzarella, sodium reduction, functionality, flavor

\section{INTRODUCTION}

Sodium is an essential nutrient and plays a vital role in maintaining osmotic balance in the body and in sustaining healthy nerve function (Lang, 2007). High levels of dietary sodium intake, however, elevate blood pressure, which greatly increases the risk of stroke, heart disease, cardiac failure, and kidney disease (Doyle and Glass, 2010). Reducing dietary sodium intake has a direct progressive effect on lowering blood pressure in select populations (He and MacGregor, 2010). The average sodium intake in the United States is $3,600 \mathrm{mg} / \mathrm{d}$. The US dietary guidelines set the safe minimum intake level at $500 \mathrm{mg}$ of sodium/d and the upper intake level at $2,300 \mathrm{mg} / \mathrm{d}$ (US Department of Agriculture, 2010). Other countries with lower average sodium intakes, such as Canada, the United Kingdom, and Australia, have set similar guidelines that propose adequate intake levels from 460 to $1,500 \mathrm{mg} / \mathrm{d}$ and upper intake limits from 2,200 to 2,400 mg/d (NHMRC, 2006; Health Canada, 2010; Wyness et al., 2012; WHO, 2013). To achieve these dietary intake levels, the demand for reduced-sodium foods is increasing.

Salt (as sodium chloride) was historically added to food primarily as a preservative. With advances in food processing and food safety practices, its current role is primarily as a flavor enhancer. Nearly $75 \%$ of dietary sodium is derived from processed foods containing added sodium chloride, whereas only $5 \%$ of dietary sodium is naturally occurring (US Department of Agriculture, 2010). Retail US cheeses contain varying sodium levels, with mean levels ranging from $615 \mathrm{mg} / 100 \mathrm{~g}$ in Cheddar cheese, to 1,242 mg/100 g in process cheese (Agarwal et al., 2011). The annual per capita consumption of cheese in the United States is $15.3 \mathrm{~kg}$ (CDIC, 2013), which equates to a daily consumption of $42 \mathrm{~g}$ of cheese. This provides 250 to $500 \mathrm{mg}$ of sodium depending on the cheese type consumed, the upper range of which 
meets current adequate intake levels. Cheese is also a component of multi-component foods such as pizzas, pastas, and quesadillas, where overall sodium reduction can be achieved by slightly reducing the sodium content of individual components. Hence, there is interest in manufacturing low- and reduced-sodium cheeses in the United States. However, this creates challenges for the traditional cheese manufacture process (Schroeder et al., 1988; Apostolopoulos et al., 1994).

During cheese making, salt addition facilitates curd syneresis and whey extraction from the curd, thus aiding in curd dehydration (Guinee and Fox, 2004). This process gives the cheese a firmer texture and increases the ionic strength of the cheese. Salt, along with low temperature, acid $\mathrm{pH}$, and low moisture, slows the rate of acid development and shifts starter culture metabolism toward amino acid degradation for flavor compound formation (Guinee, 2004; Xie et al., 2004). Additionally, salt prevents undesirable bacterial growth in cheese during cold storage and contributes to desirable flavor and performance attributes (Doyle and Glass, 2010). Saltiness itself is one of the most important flavor attributes in cheese (Liem et al., 2011) and is directly correlated with overall desirability by consumers (Schroeder et al., 1988).

When salt is reduced, curd dehydration is altered, and hence, the moisture and $\mathrm{pH}$ values of the resultant cheeses may vary, which will in turn alter cheese quality. Recent studies have attempted to manufacture reduced-salt cheese by standard processes and have confirmed that moisture retention increases with salt reduction in cheese (Grummer and Schoenfuss, 2011; Shrestha et al., 2011), consistent with older studies (Schroeder et al., 1988). One group previously achieved similar moisture levels in Cheddar cheeses at $1.25 \%$ salt (40\% reduction from $1.8 \%$ ) but at a lower moisture level of $35 \%$ (Lindsay et al., 1982), whereas current commercial cheeses have a higher moisture content of 37 to $38 \%$. Another group (Møller et al., 2013) performed a study at 4 salt levels in Cheddar cheese and characterized the flavor compound changes, rheological changes, and descriptive sensory analysis in the cheeses with a minimally trained panel (only $8 \mathrm{~h}$ of training). The study showed that the extent of proteolysis and free amino acid levels increase with lower salt levels in cheeses, which might increase the risk of bitterness. Interestingly, the study found no differences in rheological properties among the cheeses, noted development of bitterness with reduced salt, and suggested that total salt levels of 1.7 to $2.3 \%$ that are comparable to retail full-salt cheese levels provided cheeses with low bitterness and increased sapid flavors. They also showed that reducing salt levels linearly reduced perception of the basic tastes (salty, sour, bitter, sweet, and umami).
However, the afore-mentioned studies lacked a consumer panel, which is needed to understand whether regular consumers perceive salt reduction in cheeses. The aforementioned studies were exclusively done in Cheddar cheese, whereas cheese type and serving style may also influence consumer perception of salt levels.

In order to understand how salt levels alter flavor perceptions by consumers and study the role of salt on cheese functionality, cheeses need to be manufactured with lower sodium content and still maintain $\mathrm{pH}$ and moisture levels comparable to that of standard cheeses. We hypothesized that a $30 \%$ salt reduction is sufficient to alter consumer perceptions of cheese acceptability. Our objectives were to develop methods to manufacture full-fat Cheddar cheese and low-moisture, part-skim Mozzarella cheese (hereafter referred to as Mozzarella cheese) at different salt levels with similar moistures and $\mathrm{pH}$ within cheese type, and to determine how salt reduction below current retail levels, independent of cheese moisture and $\mathrm{pH}$, alters cheese functionality, flavor, and consumer acceptability. Toward these goals, we manufactured full-fat Cheddar cheese and Mozzarella cheese at 5 salt levels ranging from 0.7 to $1.8 \%$. Cheeses were served to consumer panelists individually and on pizzas or quesadillas to evaluate the role of serving style in saltiness perception.

\section{MATERIALS AND METHODS}

\section{Cheddar Cheese Manufacture}

In order to make cheese with the desired $\mathrm{pH}$, moisture, and salt levels, 48 blocks of cheese were made with varying manufacturing procedures. Of these, 15 blocks of cheese with salt levels most closely matching the targets were selected to give 3 replicates at each salt level. The method that proved most successful in obtaining consistent $\mathrm{pH}$ and moisture levels and at salt target levels of $0.7,1.0,1.25,1.35$, and $1.8 \%$ (wt/wt) is listed below.

Fresh cow milk was obtained from Utah State University's George B. Caine Dairy Research and Teaching Center (Wellsville) and transported to the Gary Haight Richardson Dairy Products Laboratory at Utah State University (Logan). The milk was standardized to a protein-to-fat ratio of 0.83 for making full-fat cheeses, and was HTST-pasteurized (plate heat exchanger; APV Crepaco, Chicago, IL) at $73^{\circ} \mathrm{C}$ for 15 s. Aliquots of $680 \mathrm{~kg}$ of milk were pumped into a Tetra Scherping horizontal cheese vat (Tetra Pak Cheese and Powder Systems Inc., Winsted, MN) and warmed to $31^{\circ} \mathrm{C}$. The following cultures were added: $80 \mathrm{~g}$ of DVS 850 ( $\mathrm{Lac}$ tococcus lactis), $30 \mathrm{~g}$ of DVS CR319 (lactose-negative Lc. lactis), and $15 \mathrm{~g}$ of DVS LH32 (Lactobacillus helve- 
ticus adjunct (all from Chr. Hansen Labs, Milwaukee, WI), followed by addition of $85 \mathrm{~mL}$ of calcium chloride (Nelson-Jameson, Marshfield, WI), and the milk was allowed to ripen for $30 \mathrm{~min}$. The milk was then set with $51 \mathrm{~mL}$ of double-strength chymosin (Maxiren, DSM Food Specialties, Parsippany, NJ) for 30 min and cut. The curd was allowed to heal for 5 min and then stirred gently for $25 \mathrm{~min}$. The curd was then cooked and stirred as indicated in Table 1. Aliquots of onethird of the curd and whey were then pumped into 3 open vats and drained at the $\mathrm{pH}$ values listed in Table 1. The curd was then drained, dry stirred, cheddared, milled, and salted as indicated in Table 1. Briefly, the curd was weighed and salt added to correspond to salt reductions of $0,25,33,50$, and $60 \%$. After salting, 12 $\mathrm{kg}$ of curd was packed into Wilson hoops and pressed at $80 \mathrm{kPa}$ overnight $(\sim 18 \mathrm{~h})$ at room temperature $\left(\sim 20^{\circ} \mathrm{C}\right)$ into nominal $10-\mathrm{kg}$ blocks. The cheeses were vacuumpackaged and stored at $6^{\circ} \mathrm{C}$ for aging. Proximate analysis was conducted at $5 \mathrm{~d}$ of age. Fifteen blocks of cheese with salt levels most closely matching the targets were selected to give 3 replicates at each salt level. These cheeses had a final moisture content of 36 to $38 \%$, $\mathrm{pH} 5.0$ to 5.2 , and fat-on-dry basis of 51 to $53 \%$. The cheeses at 5 salt levels were aged up to 6 mo and then used for sensory panels.

\section{Mozzarella Cheese Manufacture}

The targeted salt levels in Mozzarella cheese were $1.9,1.35,1.2,0.9$, and $0.75 \%$, which corresponded to $0,25,33,50$, and $60 \%$, salt reductions, respectively. Fresh cow milk was obtained from Utah State University's Caine Dairy Research and Teaching Center. Cold milk was transported to the Gary Haight Richardson Dairy Products Laboratory and $680-\mathrm{kg}$ batches were standardized to a protein-to-fat ratio of 1.2. The milk was HTST-pasteurized $\left(73^{\circ} \mathrm{C}\right.$ for $\left.15 \mathrm{~s}\right)$ and pumped into a Tetra Scherping horizontal cheese vat (Tetra Pak Cheese and Powder Systems) and warmed to $34.5^{\circ} \mathrm{C}$. Streptococcus thermophilus starter culture TS-10A (DSM Food Specialties) was added at the rate of 4.7 $\mathrm{g} / 100 \mathrm{~kg}$ of milk and allowed to ripen for $45 \mathrm{~min}$. The milk was set with chymosin (Maxiren) using $9 \mathrm{~mL} / 100$ $\mathrm{kg}$ of milk, stirred for $2 \mathrm{~min}$, and then allowed to coagulate without stirring until a firm set was reached (30 min). The curd was cut, allowed to heal for $5 \mathrm{~min}$, and then stirred for $20 \mathrm{~min}$ at $10 \mathrm{rpm}$. The temperature was increased to $40.5^{\circ} \mathrm{C}$ over 30 min while stirring at 10 rpm, stirred for an additional $30 \mathrm{~min}$, and then pumped to a drain table (Kusel Equipment Co., Watertown, WI). The curd and whey were stirred for $15 \mathrm{~min}$ and then one-third of the whey was drained; this process was repeated until all the whey was drained. The dry curd was stirred for $30 \mathrm{~min}$ and then washed with sufficient water at $10^{\circ} \mathrm{C}$ to reduce the curd temperature to $21^{\circ} \mathrm{C}$. The $\mathrm{pH}$ at this point ranged from 5.25 to 5.30 . A portion of the finished curd $(11.5 \mathrm{~kg})$ was transferred to containers and the requisite amount of salt was added in 3 applications at 5 -min intervals. The curd was processed by a single-screw cooker-stretcher with salt levels in brine and temperature of the cookerstretcher as shown in Table 2. The curd was extruded into 5-cm-diameter polyvinyl chloride tubes $60 \mathrm{~cm}$ long. Five tubes of cheese were collected for each salt treatment and cooled in ice water. The cooled cheese was vacuum-packaged and stored at $5^{\circ} \mathrm{C}$ until analysis. Cheese making was replicated thrice on different days using different batches of milk, and cheeses that most closely matched the target salt levels were selected for storage and testing.

\section{Proximate Analysis}

Moisture content was determined in triplicate using a microwave oven (CEM Corp., Matthews, NC) at $70 \%$ power with an endpoint setting of $<0.4 \mathrm{mg}$ of weight change over 2 s (Oommen et al., 2002). Fat content was determined using a modified Babcock method (Richardson, 1985). Salt was measured in triplicate by homogenizing grated cheese $(5 \mathrm{~g})$ with distilled water $(98.2 \mathrm{~g})$ for $4 \mathrm{~min}$ at $260 \mathrm{rpm}$ in a Stomacher 400 (Seward, London, UK). The slurry was filtered through Whatman \#1 filter paper, and the filtrate was analyzed

Table 1. Processing parameters that were altered for manufacture of reduced-sodium Cheddar cheeses

\begin{tabular}{lccccc}
\hline & \multicolumn{5}{c}{ Salt target (\%) } \\
\cline { 2 - 6 } Processing step & 1.80 & 1.35 & 1.25 & 1.00 & 0.75 \\
\hline Cook temperature $\left({ }^{\circ} \mathrm{C}\right)$ & 39.2 & 39.2 & 39.7 & 40.3 & 40.8 \\
Cook time (min) & 35 & 35 & 38 & 48 & 58 \\
Drain pH & 6.30 & 6.30 & 6.16 & 6.06 & 6.00 \\
Dry stir time (min) & 0 & 0 & 5 & 10 & 15 \\
Mill pH & 5.40 & 5.40 & 5.65 & 5.65 & 5.65 \\
Salt added to $12.0 \mathrm{~kg}$ of curd $(\mathrm{g})$ & 289 & 210 & 170 & 125 & 90 \\
\hline
\end{tabular}


Table 2. Salt addition and cooker-stretcher conditions for manufacture of reduced-sodium Mozzarella cheeses

\begin{tabular}{lccccc}
\hline & \multicolumn{5}{c}{ Salt target (\%) } \\
\cline { 2 - 6 } Processing step & 1.80 & 1.35 & 1.25 & 0.90 & 0.70 \\
\hline Salt added to 11.3 kg of curd $(\mathrm{g})$ & 231 & 156 & 130 & 104 & 75 \\
Cooker-stretcher brine $(\%)$ & 5.1 & 3.5 & 3.2 & 2.3 & 1.9 \\
Cooker-stretcher temperature $\left({ }^{\circ} \mathrm{C}\right)$ & 71.0 & 68.3 & 65.5 & 62.8 & 60 \\
\hline
\end{tabular}

for sodium chloride using a chloride analyzer (model 926, Corning, Medfield, MA). The $\mathrm{pH}$ was measured using a standard glass electrode in a solution of $20 \mathrm{~g}$ of cheese and $10 \mathrm{~g}$ of distilled water that was homogenized at $260 \mathrm{rpm}$ for $1 \mathrm{~min}$ with the Stomacher 400.

\section{Texture Profile Analysis}

Texture profile analysis (hardness, adhesiveness, cohesiveness, resilience, chewiness, and springiness) of Cheddar cheese was performed in triplicate after 3 and 6 mo of storage at $6^{\circ} \mathrm{C}$ using a two-bite compression test as described by Bourne (1968) using a Texture Analyzer TA.XT plus (Stable Micro Systems, Godalming, UK) equipped with 2-kg load cell. Cheese samples were cut into cylinders $10 \mathrm{~mm}$ in diameter $\times 20 \mathrm{~mm}$ in length) using a cork borer, tempered for $\sim 1 \mathrm{~h}$ at room temperature $\left(\sim 22^{\circ} \mathrm{C}\right)$, and then tested using a crosshead speed of $20 \mathrm{~mm} / \mathrm{min}$ and $60 \%$ compression.

\section{Stretch Test}

After 2 and 8 wk of storage at $4^{\circ} \mathrm{C}$, stretchability of the Mozzarella cheeses was characterized using the Utah State University (USU) stretch test as described by Fife et al. (2002) and modified by Moyes (2003). Cheeses were finely shredded and $50 \mathrm{~g}$ of each was pressed into a stainless-steel sample cup, and then tempered in a $65^{\circ} \mathrm{C}$ water bath for $45 \mathrm{~min}$. Once tempered, sample cups were placed into a water-jacketed cup to maintain sample temperature during the test. The TA.XT plus texture analyzer was fitted with a 3-prong sample probe and set to pull the probe up through the cheese to a height of $205 \mathrm{~mm}$ above the base of the sample cup. The load exerted on the probe as it was pulled through the cheese at a crosshead speed of 1 $\mathrm{cm} / \mathrm{min}$ was recorded 25 times/s. Melt strength $\left(\mathbf{F}_{\mathbf{M}}\right)$, which is defined as the maximum load obtained during the test and occurs when the probe is pulled through the melted cheese mass, was calculated.

\section{Melt Test}

After 2,4 , and 8 wk of storage at $4^{\circ} \mathrm{C}$, the melting properties of Mozzarella cheeses were characterized using a UW Meltmeter (Wang et al., 1998). Briefly, quadruplicate cheese samples, $3 \mathrm{~cm}$ in diameter and $0.7 \mathrm{~cm}$ in height, were tested at $60^{\circ} \mathrm{C}$, with the height of cheese recorded every $0.2 \mathrm{~s}$ for $40 \mathrm{~s}$. Initial rate of cheese flow was defined as the rate $(\mathrm{mm} / \mathrm{s})$ at which cheese height decreased during the first $5 \mathrm{~s}$ of the test. The final extent of cheese flow (decrease in height) at $40 \mathrm{~s}$ was also determined.

\section{Sensory Analysis}

To determine how salt level alters sensory acceptability, consumer panels consisting of 120 panelists each were conducted at the Utah State University Sensory Laboratory, where panelists were served cheeses in 2 different styles for each cheese type in separate panels. Mozzarella cheese was served to panelists as shreds and baked on a pizza after 3 wk of storage. Cheddar cheese was served as $1-\mathrm{cm}^{3}$ cubes and quesadillas after 3 and 6 mo of storage. Cheddar cubes and Mozzarella shreds were both served at $7^{\circ} \mathrm{C}$ (refrigerated until serving). The quesadillas and pizza were served at $60^{\circ} \mathrm{C}$. Cheddar cheese was shredded and a quarter cup of cheese was melted onto 8-inch tortilla shells using electric griddles to prepare the quesadillas. The pizza was made on 12inch crusts, with approximately one-half cup of pizza sauce and 2 cups of shredded Mozzarella cheese, and was cooked at $232^{\circ} \mathrm{C}$ for 6 min in a FastBake Lincoln Impinger conveyer oven (Lincoln Foodservice Products Inc., Fort Wayne, IN). Consumers rated the samples on a 9-point hedonic scale to denote degree of liking, where $1=$ dislike extremely, $2=$ dislike very much, $3=$ dislike moderately, $4=$ dislike slightly, $5=$ neither like nor dislike, $6=$ like slightly, $7=$ like moderately, $8=$ like very much, and $9=$ like extremely. Samples were presented to panelists in a completely randomized block design.

The role of salt level in the flavor profile of the cheeses was characterized by descriptive sensory analysis. Panels were conducted at the Utah State University Sensory Laboratory when Mozzarella cheeses were $3 \mathrm{wk}$ old and when Cheddar cheeses were 3 and 6 mo old. Eight trained panelists with $50 \mathrm{~h}$ of training were used. Training procedures and conduct of descriptive sensory panels have been described previously (Martini et al., 2009). The panelists were served cubed cheese samples 
at room temperature and were requested to note 19 different flavors in the cheeses (bitter, brothy, buttery, cooked, fishy, fruity, lactone/fatty acid, metallic, nutty, oxidized, pineappley, rancid, rosy/floral, salty, sour, sulfur, sweet, umami, whey) and rate each of these attributes on a 15-point categorical scale.

\section{Statistical Analysis}

All cheeses were made in triplicate on different days from different batches of milk. Proximate data and texture profile analysis data from cheeses were analyzed using a split-plot design in JMP software version 7 (SAS Institute Inc., Cary, NC). All sensory data was collected using SIMS 2000 software (SIMS Sensory Software, Morristown, NJ) and analyzed using SAS software version 9.1.3 (SAS Institute Inc.). Two-way ANOVA was used to analyze how salt level altered liking scores. Significance was inferred at $\alpha=0.05$.

\section{RESULTS}

\section{Mozzarella}

Mean composition of the Mozzarella cheeses is shown in Table 3. Moisture, $\mathrm{pH}$, and fat levels of the cheeses were similar, and mean salt contents were $1.88,1.35$, $1.19,0.90$, and $0.74 \%$, with the target corresponding to $0,25,33,50$, and $60 \%$ salt reductions, respectively.

Overall, meltability of the cheeses increased slightly (i.e., the initial and final extent of melting increased) when salt content was reduced up to $50 \%$. Notably, meltability of the cheese containing $0.7 \%$ salt alone was comparable to that of the control cheese (Figure 1). This was evident throughout storage, and meltability of all cheeses increased with age, as expected. In contrast, the cheeses with lower salt content had lower stretch- ability scores $\left(\mathrm{F}_{\mathrm{M}}\right)$ than the control cheese $(P \leq 0.05$; Figure 2). The greatest reduction in stretchability occurred with a $25 \%$ reduction in salt levels and became more apparent when cheeses reached 8 wk of storage. At wk 8 , all cheeses stretched well, with the $0.9 \%$ salt cheese being the most fluid and least elastic $(P \leq 0.05)$, and therefore requiring the least $\mathrm{F}_{\mathrm{M}}$ when stretched.

Lowering the salt content of Mozzarella cheese reduced its liking score when consumed as shreds or on a pizza (Figure 3). The overall trend was for a lower liking score at each salt reduction step $(25,33,50$, and $60 \%$ ), although when cheese was consumed as shreds, the scores for the 25 and $33 \%$ salt-reduced cheeses were not significantly different from that of the control cheese. Liking scores for shreds and pizzas were similar for the control and 25\% salt-reduced cheese, and for the 25 and $33 \%$ salt-reduced cheeses. At $50 \%$ salt reduction, the liking score when cheese was consumed as shreds was only 5.7 (below "like slightly"), whereas when cheese was consumed on a pizza, its liking was greater than "like slightly" with a score of 6.5. The serving style of cheese had a greater effect at this salt range, illustrated by the liking score decreasing almost 1 point when cheese was consumed as shreds with between 50 and $33 \%$ salt reduction $(P \leq 0.05)$ compared with no significant difference when cheese was consumed on a pizza. Consumer liking decreased further when salt content was lowered to $0.7 \%$ (the level needed to fit into the low-sodium category in the United States). When this cheese was consumed as shreds, the mean score was only 4.9 (below "neither like nor dislike"), whereas when consumed on a pizza, it was in the "like slightly" range with a mean score of 6.2 .

Descriptive panelists perceived bitter, cooked, fishy, fruity, metallic, nutty, oxidized, pineapple, rancid, rosy/ floral, sweet, and whey flavors similarly across all salt

Table 3. Proximate composition of cheeses made at different sodium levels ${ }^{1}$

\begin{tabular}{lcccc}
\hline $\begin{array}{l}\text { Salt reduction } \\
\text { target (\%) }\end{array}$ & Salt target $(\%)$ & Salt in cheese ${ }^{2}(\%)$ & Moisture (\%) & $\mathrm{pH}$ \\
\hline $\begin{array}{l}\text { Cheddar cheese } \\
0\end{array}$ & 1.8 & $1.85 \pm 0.03$ & $35.0 \pm 0.6$ & $5.3 \pm 0.1$ \\
25 & 1.35 & $1.38 \pm 0.08$ & $37.4 \pm 0.7$ & $5.0 \pm 0.0$ \\
33 & 1.21 & $1.28 \pm 0.00$ & $37.8 \pm 0.5$ & $5.1 \pm 0.0$ \\
50 & 0.9 & $0.98 \pm 0.06$ & $36.7 \pm 0.5$ & $5.1 \pm 0.2$ \\
60 & 0.7 & $0.74 \pm 0.03$ & $36.7 \pm 0.3$ & $5.0 \pm 0.0$ \\
Mozzarella cheese & & & & \\
0 & 1.8 & $1.88 \pm 0.02$ & $47.3 \pm 0.9$ & $5.4 \pm 0.2$ \\
25 & 1.35 & $1.35 \pm 0.00$ & $47.8 \pm 0.5$ & $5.4 \pm 0.2$ \\
33 & 1.21 & $1.19 \pm 0.04$ & $47.2 \pm 0.2$ & $5.4 \pm 0.2$ \\
50 & 0.9 & $0.90 \pm 0.02$ & $47.7 \pm 0.2$ & $5.5 \pm 0.2$ \\
60 & 0.7 & $0.74 \pm 0.04$ & $48.4 \pm 0.2$ & $5.5 \pm 0.1$
\end{tabular}

${ }^{1}$ Fat content was not significantly different within cheese type and was $30 \%$ for Cheddar and $18 \%$ for Mozzarella. Values are reported as mean \pm SD from triplicate sample analyses.

${ }^{2} \mathrm{CV}$ for salt targets $=0.01$ to $6.5 \%$. 

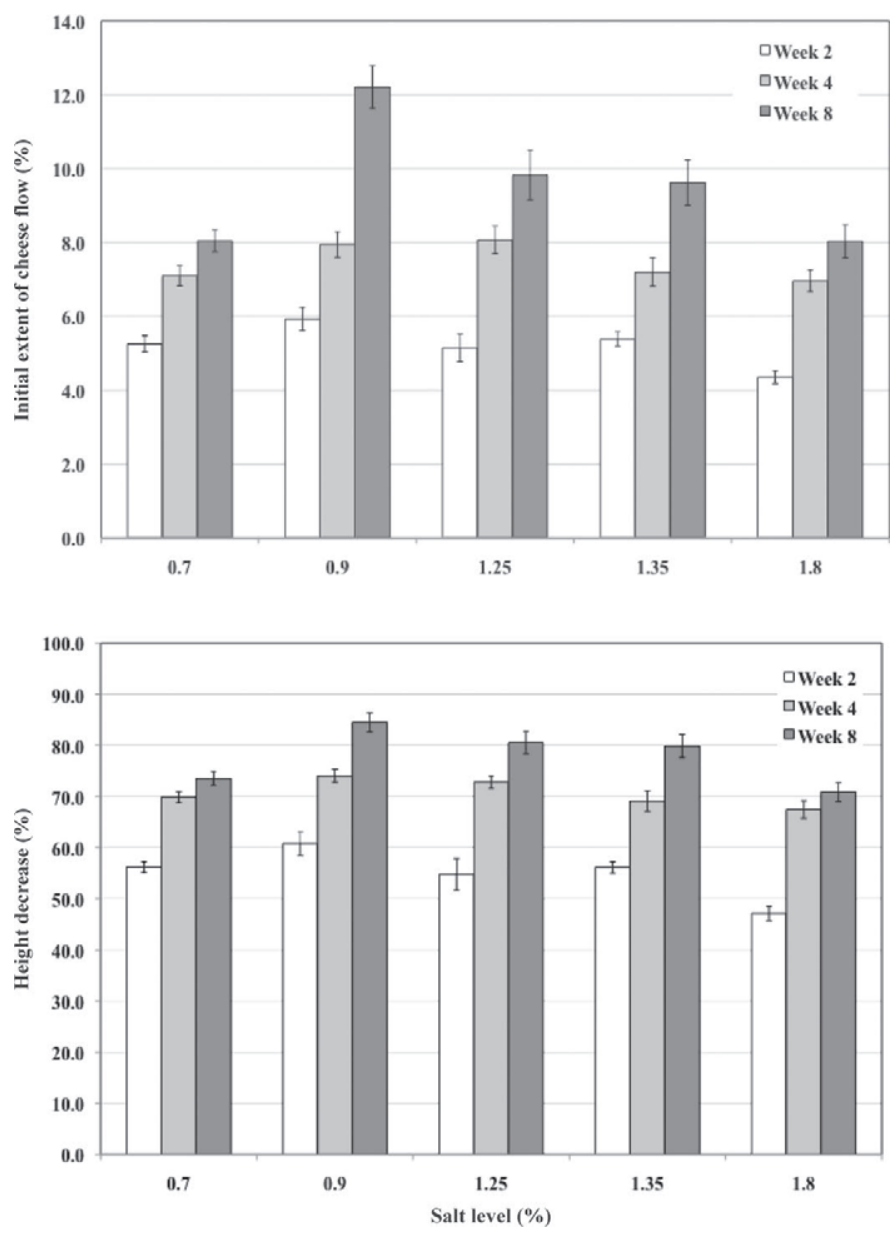

Figure 1. Initial extent of Mozzarella cheese flow (defined as the percentage of decrease in cheese height during first $5 \mathrm{~s}$ of melting; top panel) and final extent of cheese flow (defined as the percentage of decrease in cheese height at $40 \mathrm{~s}$ of melting; bottom panel).

levels in 3-wk-old Mozzarella cheese (data not shown). However, in addition to saltiness, brothy, buttery, lactone/fatty acid, sour, sulfur, and umami flavors were perceived significantly less with lower salt levels $(P$ $\leq 0.05$; Figure 4$)$. Interestingly, even though sourness perception decreased with lower salt levels $(P \leq 0.05)$, the $\mathrm{pH}$ of the cheeses was similar (Table 1$)$. Other offflavors were not detected in any of the cheeses.

A lack of salty flavor was probably the main contributor to the lower liking scores received by cheeses with 0.9 and $0.7 \%$ salt. These cheeses also had lower intensity scores $(P \leq 0.05)$ for brothy, salty, sour, umami, sulfur, and buttery flavor attributes compared with the higher salt level cheeses.

\section{Cheddar}

When salting cheese curd during Cheddar cheese manufacture, more whey was expelled at the higher salt

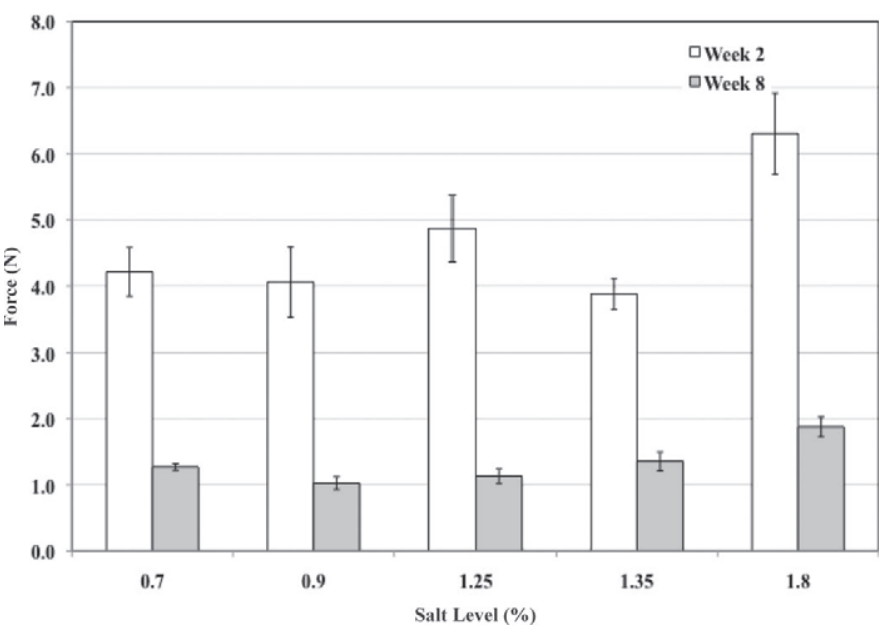

Figure 2. Results of the Utah State University (USU) melt strength test for all Mozzarella cheeses, depicting maximum melt strength (force).
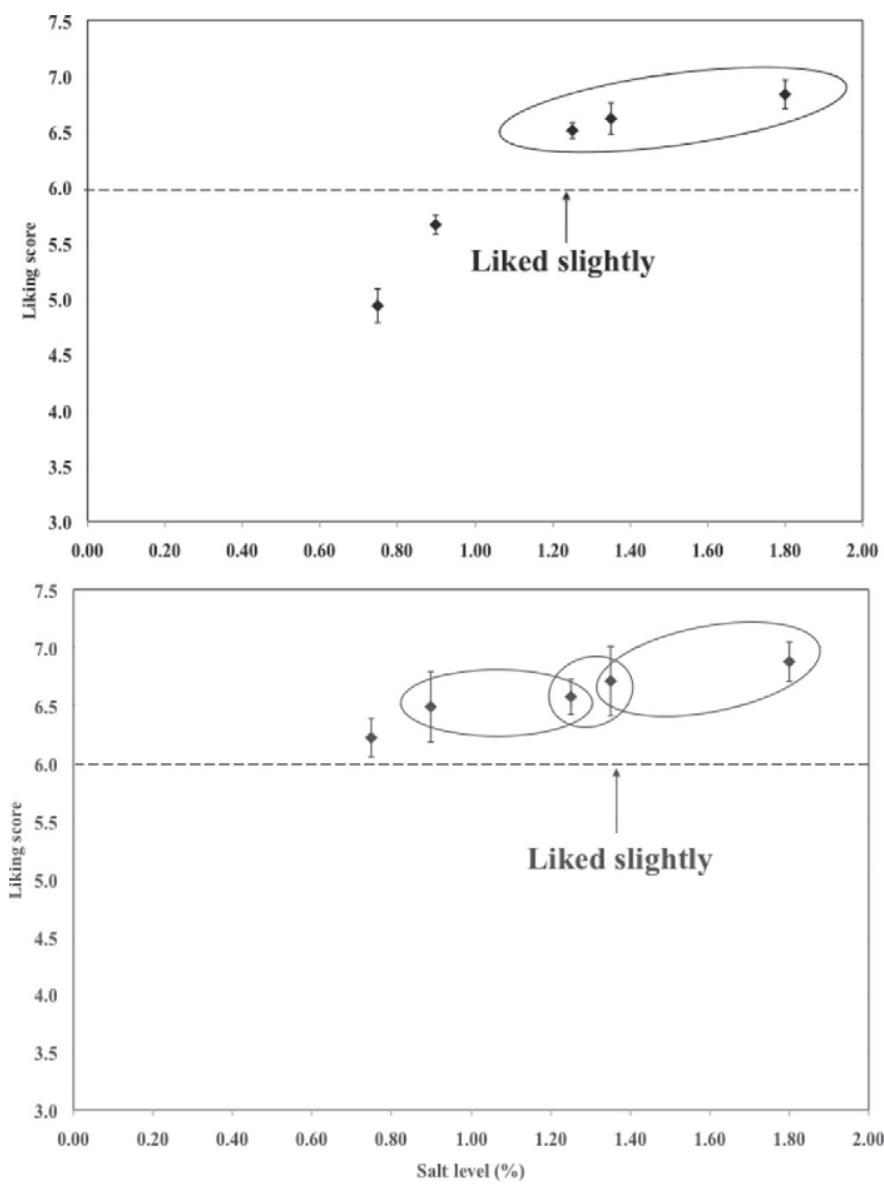

Figure 3. Average degree of liking for reduced-sodium Mozzarella cheese served as cheese shreds (top panel) and as pizza toppings (bottom panel). Data points not enclosed in a single ellipse are significantly different $(P \leq 0.05)$ from each other. 


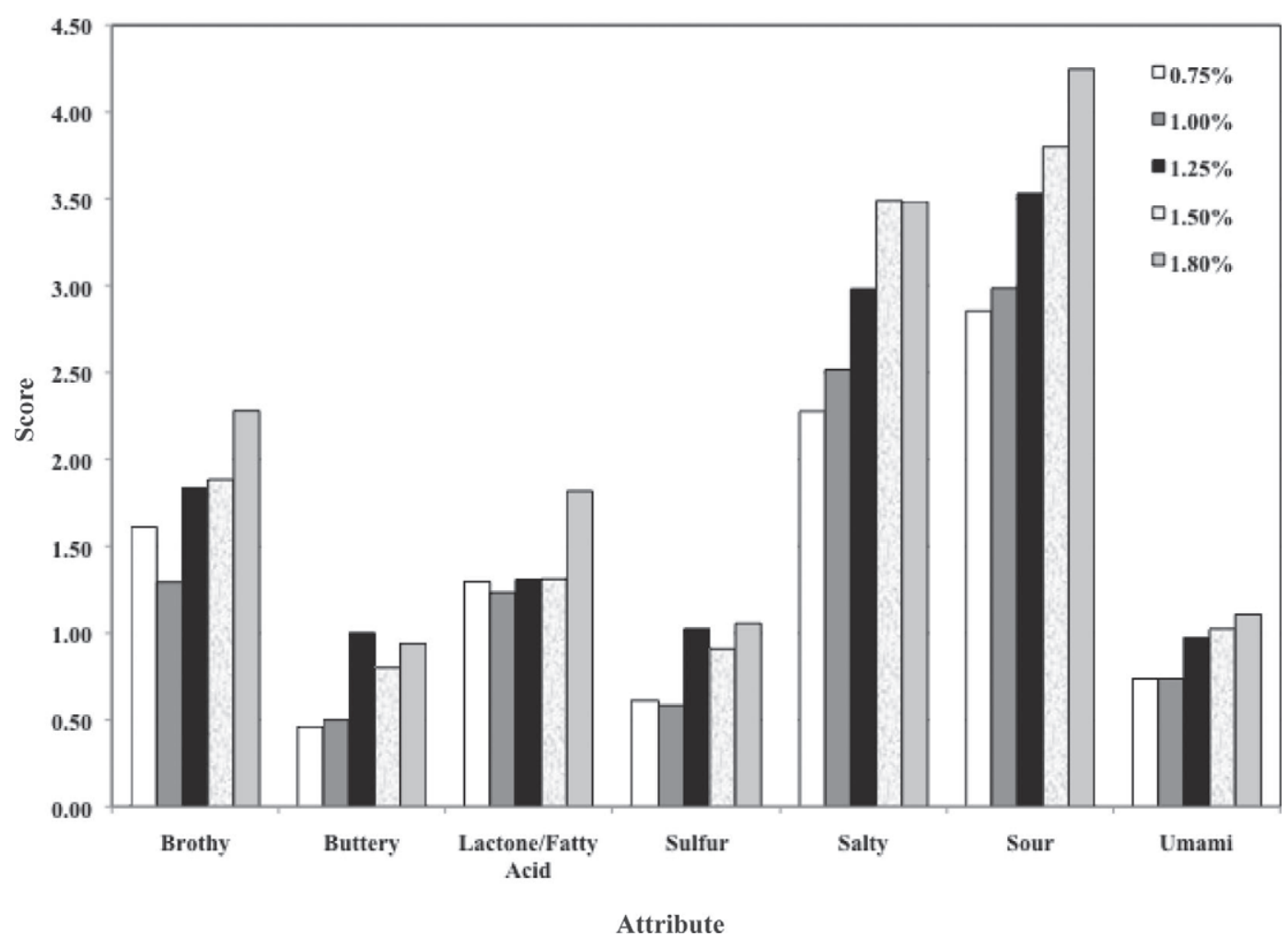

Figure 4. Descriptive panel scores (average of 8 panelists) of reduced-sodium Mozzarella cheeses (salt levels of 0.75, 1.00, 1.25, 1.50, and $1.80 \%)$. Only statistically significantly different $(P \leq 0.05)$ attributes are shown.

additions, and thus, salt added for the control $(1.8 \%$ salt) cheese included an extra $35 \%$. At the lowest salt level $(0.7 \%)$, only $7 \%$ was additionally needed because of the negligible whey loss during salting and a small loss during pressing. Cheeses at the 5 salt levels had similar moisture levels (Table 3). Unlike the Mozzarella cheese, in which salting did not influence cheese $\mathrm{pH}$, lowering the salt level did result in a decrease in $\mathrm{pH}$ from $\mathrm{pH} 5.3$ in the control Cheddar cheese to a mean $\mathrm{pH}$ of 5.0 to 5.1 for all the lower salt cheeses (Table 3 ).

At $3 \mathrm{mo}$ of storage, resilience, cohesiveness, and hardness did not change as a function of salt level. The $1.5 \%$ salt cheese had the lowest mean scores at 3 mo for springiness, adhesiveness, and chewiness; the $1.25 \%$ salt cheese had the lowest mean scores for cohesiveness and resilience; and the $1.0 \%$ cheese had the lowest mean scores for hardness, respectively (Figure 5). With further aging to $6 \mathrm{mo}$, cohesiveness, resilience, springiness, and chewiness of cheeses increased, whereas hardness and adhesiveness decreased.

In a similar manner to the Mozzarella cheese, consumer liking for Cheddar cheese decreased when salt was lowered $(P \leq 0.05$; Figure 6$)$ and was noted at both 3 and 6 mo of age, and whether presented as a cube of cheese or as a cheese quesadilla. The liking scores for cheese at 6 mo were slightly lower than for the 3-mo-old cheese, although the change in liking score with salt reduction was greater for the 6-mo-old cheese $(P \leq$ 0.05). As noted in Mozzarella cheeses, when evaluated by a descriptive panel, the 3-mo-old Cheddar cheeses did not differ in cooked, fishy, fruity, metallic, nutty, oxidized, pineapple, rancid, rosy/floral, sulfur, sweet, or whey flavors based on salt content (data not shown). In contrast, perception of salty and buttery flavors decreased with lowering of cheese salt content $(P \leq 0.05)$, whereas perception of bitter, brothy, lactone/fatty acid, sour, and umami flavors was higher $(P \leq 0.05$; Figure 7 , top panel). Perception of bitter, brothy, lactone/fatty acid, nutty, sulfur, sweet, and umami flavor attributes increased from being negligibly perceived at $3 \mathrm{mo}(P \leq$ 0.05; Figure 7, bottom panel) to higher levels after 6 mo of age; nutty and sweet flavors were similar at all salt levels (data not shown). The 6-mo-old cheeses exhibited an opposite trend to the 3-mo-old cheeses, wherein the perception of brothy, sweet, and umami flavors increased with higher salt content. Bitter and nutty flavor perception increased when salt was lowered $(P \leq 0.05)$, but the score changes were less than 0.5 units. Sour flavor was highest in the $25 \%$ salt-reduced cheese and slightly lower at further salt reductions $(P \leq 0.05)$. 
Cheese Cohesiveness

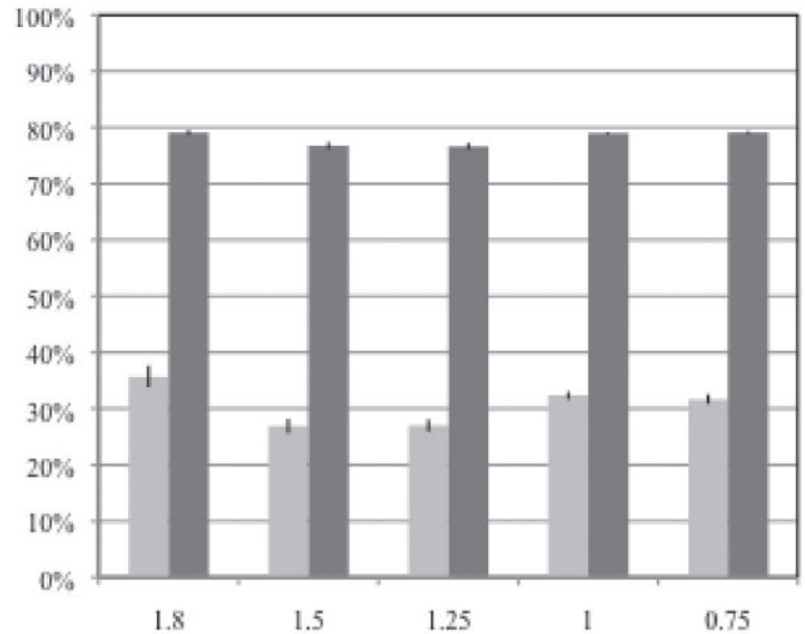

Cheese Springiness

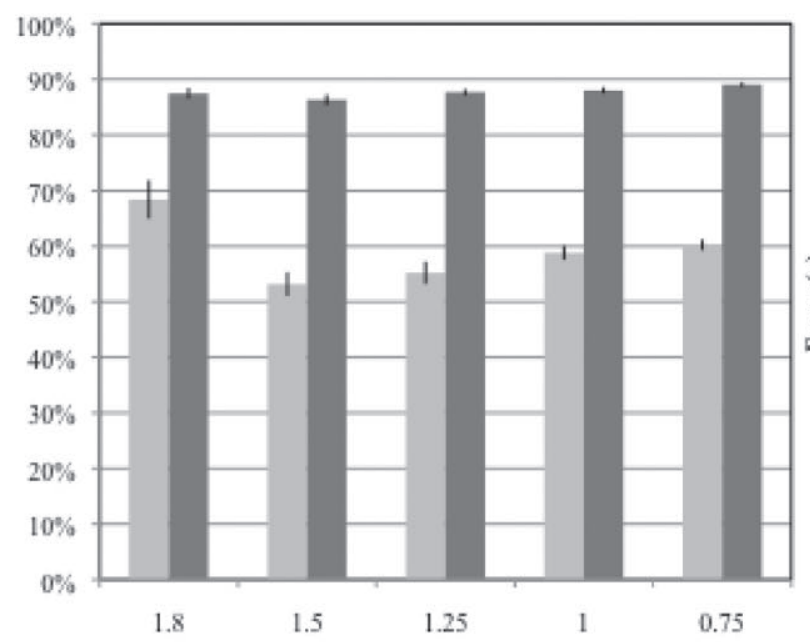

Cheese Hardness

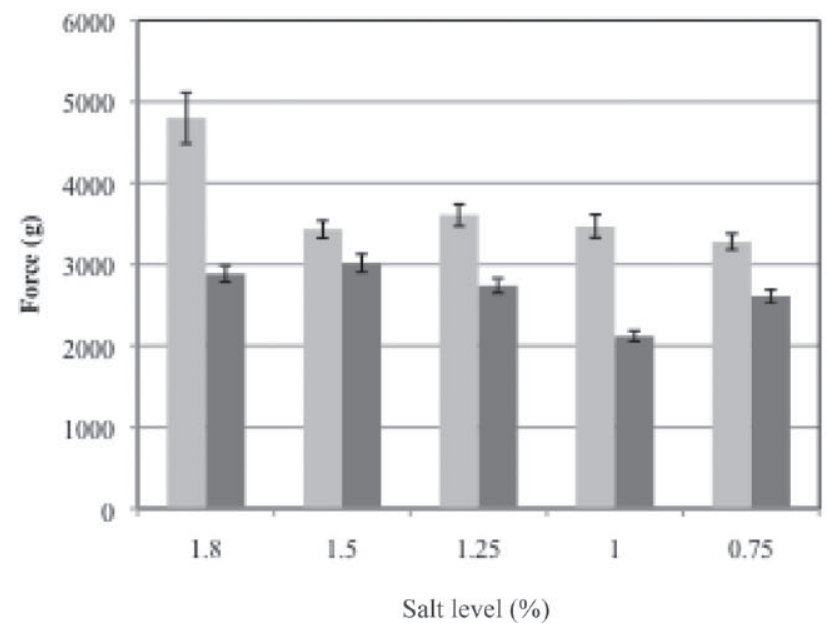

Cheese Resilience

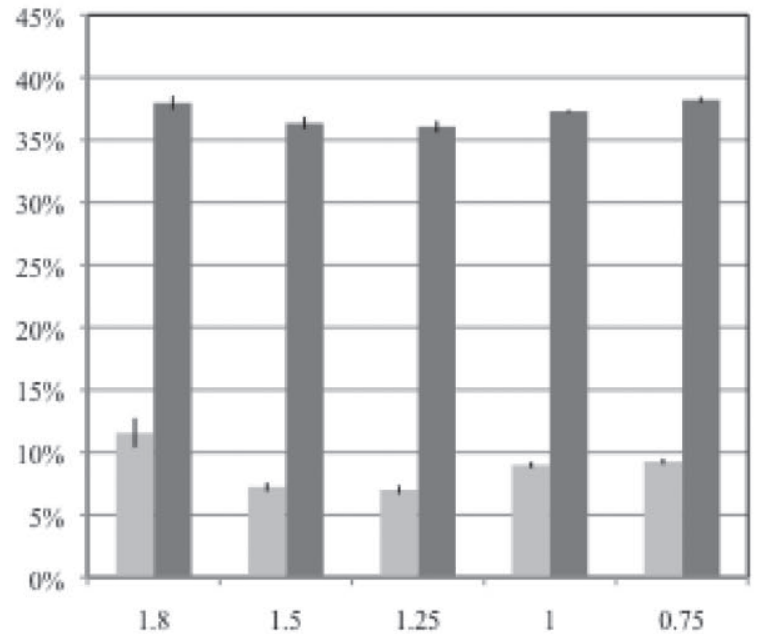

Cheese Chewiness

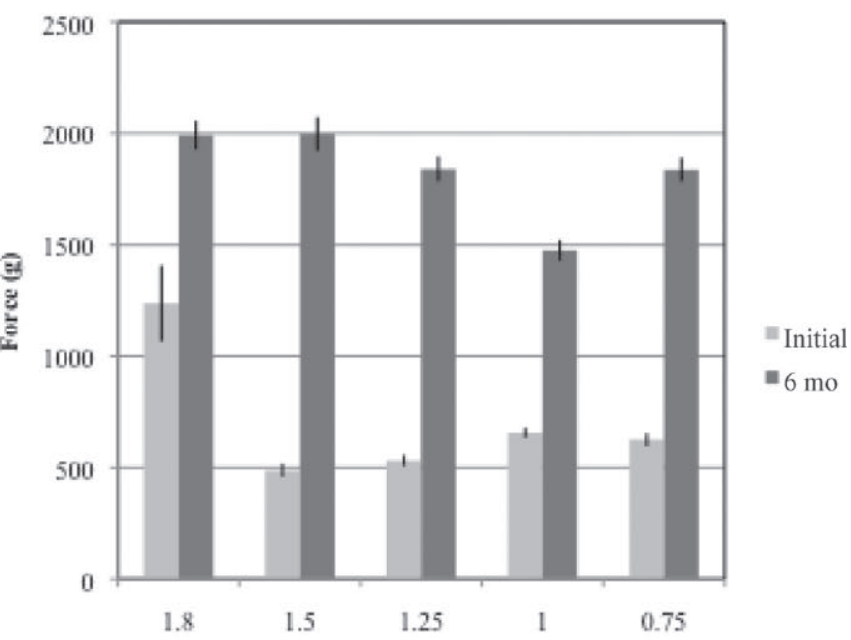

Cheese Adhesiveness

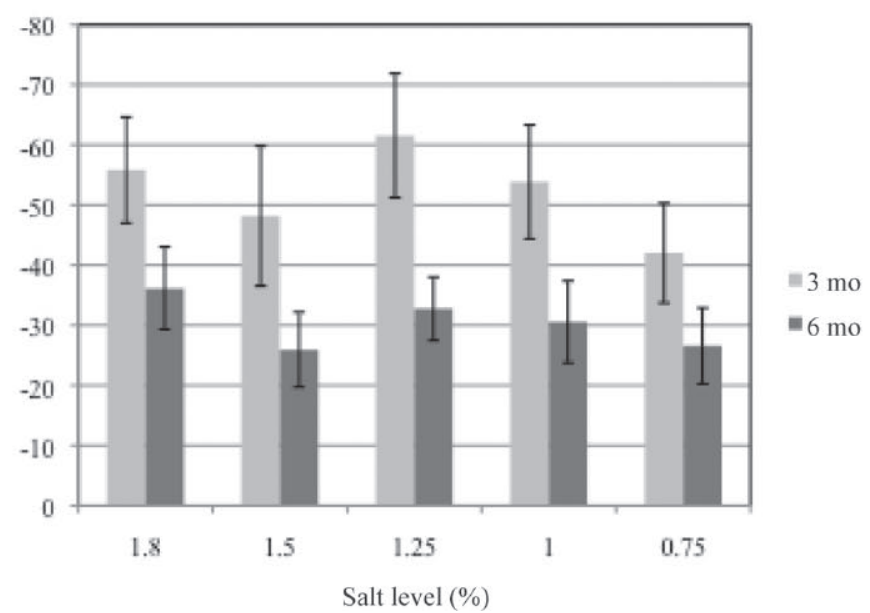

Figure 5. Texture profile analysis of Cheddar cheeses at different salt levels at 3 mo (light gray bars) and 6 mo (dark bars). 

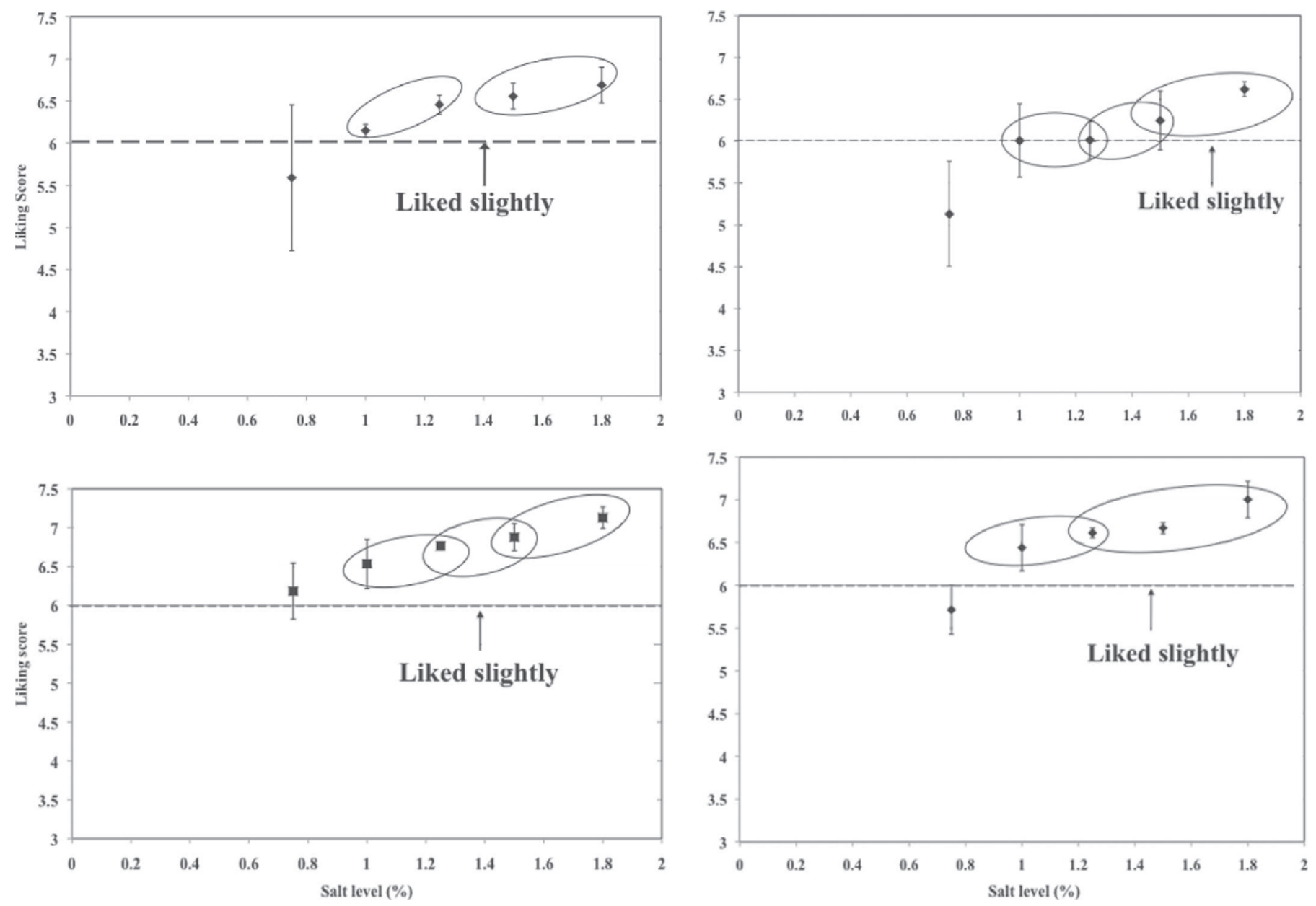

Figure 6. Average degree of liking for reduced-sodium Cheddar served as cheese cubes at 3 mo (top left panel) and 6 mo (top right panel), and served as quesadilla toppings at 3 mo (bottom left panel) and 6 mo (bottom right panel). Data points not enclosed in a single circle are significantly different $(P \leq 0.05)$ from each other.

\section{DISCUSSION}

In our study, we achieved similar cheese moisture levels across 5 salt levels ranging from 0.7 to $1.8 \%$ salt in Cheddar and Mozzarella cheeses. We chose a range of lower salt levels rather than full salt cheeses (1.8 to $2 \%$ total salt) with higher and lower salt level differences (Møller et al., 2013) due to their commercial applicability. This was also necessary to help avoid confounding factors in consumer liking and has been achieved by others over a broader salt range (Møller et al., 2013). Despite similar moisture levels, the lower salt Cheddar cheeses had lower $\mathrm{pH}$ at $1 \mathrm{wk}$ following manufacture than the higher salt cheeses, as was observed by Møller et al. (2013), where the highest salt level cheese had pH of 5.3 and lower salt levels had $\mathrm{pH}$ of 5.1 to 5.2. Perhaps, having the lesser whey expulsion after salting results in more residual lactose in the cheese and reduces salt stress on the starter lactococci, which cumulatively result in rapid fermentation of lactose into lactic acid and a greater $\mathrm{pH}$ reduction after salting the curd and during pressing and initial storage.

The changes in melting and stretch of Mozzarella cheese and in hardness and other textural attributes of Cheddar cheese that occurred during storage were comparable to those observed in previous studies. Storage of Mozzarella cheese for longer than 2 wk results in increased melting and a decrease in stretch properties (Kindstedt, 1989; Fox et al., 2000; Kuo et al, 2001; Moyes, 2003; McMahon and Oberg, 2011). This can be attributed to proteolysis occurring during storage (Oommen et al., 2002), and cheeses with lower saltin-moisture contents would be expected to have more proteolysis during storage and hence a greater increase in meltability. We observed this for Mozzarella cheese when salt was lowered from 1.8 to $0.9 \%$. Interestingly, the $0.7 \%$ salt cheese had less melting after 8 wk of storage than the $0.9 \%$ salt cheese. This suggests that 
$\square 0.75 \%$ Salt

$\square 1.00 \%$ Salt

$\square 1.25 \%$ Salt

$\square 1.50 \%$ Salt

- $1.80 \%$ Salt
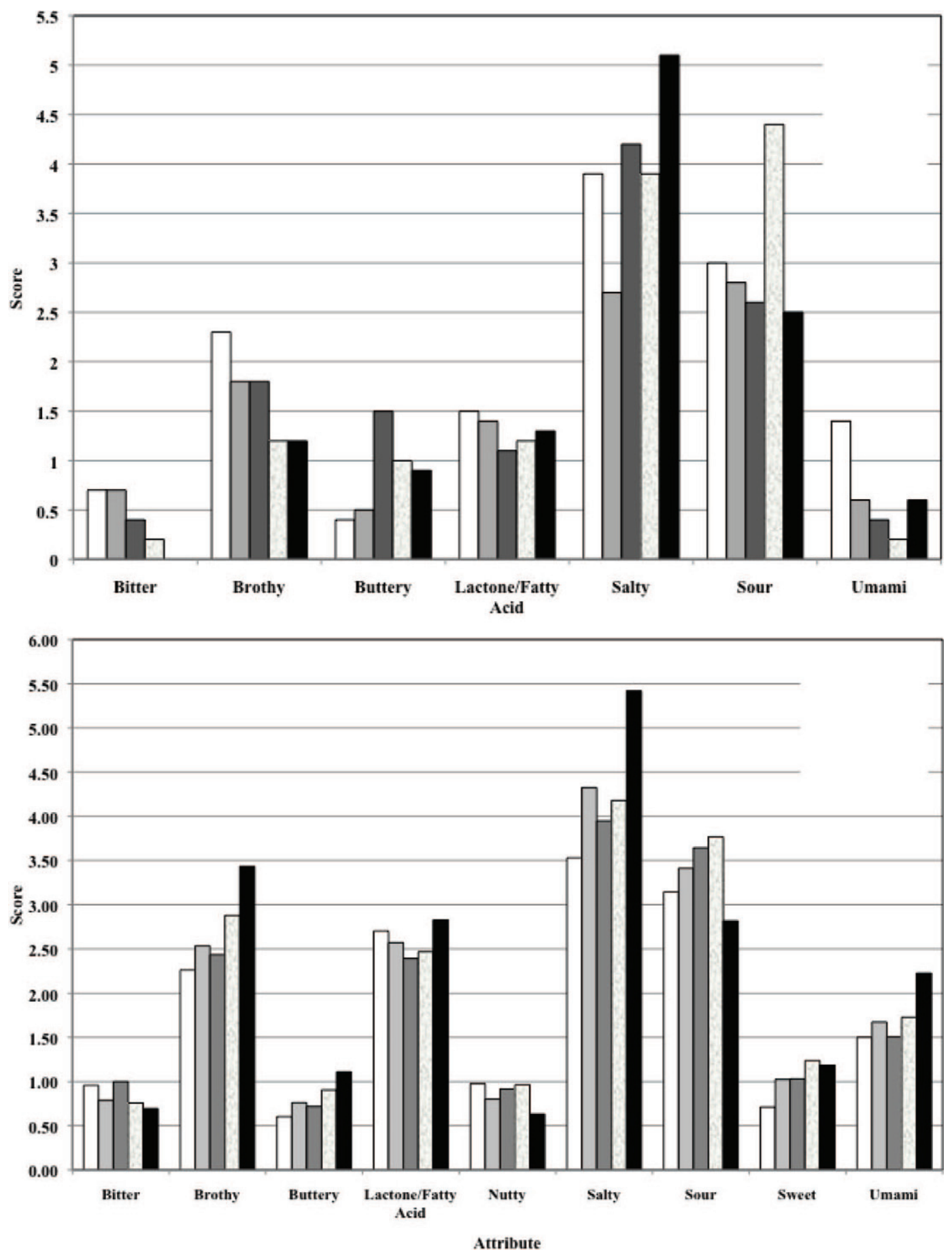

Figure 7. Descriptive panel scores (average of 8 panelists) of reduced-sodium Cheddar cheeses at 3 mo (top panel) and 6 mo (bottom panel). Only statistically significant $(P \leq 0.05)$ attributes are shown. 
a transition occurs between these salt levels in which the caseins lose solubility (Paulson et al., 1998), which overrides the effect of proteolysis on melting. For Cheddar cheese, the changes in texture with increasing salt-in-moisture content are well documented (Guinee and Fox, 2004). Some studies have held compositional parameters constant and shown a role for salt in cheese rheology (Euston et al., 2002; Guinee and Fox, 2004) primarily because of its effect on protein hydration, which affects the viscoelastic character of the cheese. We observed only slight differences in texture with changes in salt content and no persistent trends as a function of salt content.

Salty flavor scores decreased with salt reduction and ranged from 3.5 to $2.3,5.1$ to 2.6 , and 5.4 to 3.5 for Mozzarella, 3-mo-old (mild) Cheddar, and 6-mo-old (aged) Cheddar cheeses, respectively. In our study, it was apparent that consumer liking responded to even small changes in salt. These changes became evident when comparing, for example, the control versus $33 \%$ reduced-salt cheeses, or the $25 \%$ versus $50 \%$ reducedsalt cheeses. Interestingly, the consumer liking scores for Cheddar and Mozzarella cheeses had very similar trends with respect to salt content, whereas the scores of the trained descriptive panelists had different patterns of response. Even with the same level of overall salt content in the control cheeses (1.8\%), the saltiness score for Cheddar was 5.1 compared with 4.2 for Mozzarella. This may be attributed to higher salt-inmoisture in the Cheddar cheese $(5.0$ vs. $3.8 \%)$ or to other flavor components present that contribute to saltiness in Cheddar cheese but are less prevalent in Mozzarella. Cheddar cheese is characterized as having a "cheese" flavor that is considered to result from a balance of flavor compounds (Mulder, 1952) attributable to lactococcal starter cultures. Mozzarella cheese does not have the same "cheese" flavor and is characterized as having a salty-sour-milky flavor. For Mozzarella cheese, we observed a trend, over the whole salt range, for saltiness perception to decrease with salt content of the cheese. For Cheddar cheese, we detected a large decrease in saltiness with the $25 \%$ reduction and no consistent change with further salt reduction.

Based on both studies, salt may play an important role in potentiating the perception of beneficial flavor attributes, which may be based on saltiness alone in younger Cheddar cheese or in nonaged cheeses such as Mozzarella. We also noted that salty, sour, and umami attributes were perceived differently at different salt levels, which is consistent with the observations of Møller et al. (2013). In contrast, we noted that our cheeses did not develop off-flavors, such as bitter flavor, that Møller et al. (2013) reported for their study cheeses. The use of a different starter in our study might have produced cheeses that lack bitterness. From our experience over a number of years in making cheeses in our pilot plant with varying fat and salt levels, we have minimal problems with bitterness in cheese when using the DVS850 starter; thus, choosing an appropriate starter for making lower salt cheeses without flavor defects is important.

The trends in consumer liking scores for both Cheddar and Mozzarella cheeses, whether served cold or heated as part of a quesadilla or pizza, were that the cheeses with the highest salt content (1.8\%) had the highest consumer liking scores. We did not detect a statistically significant difference with a $25 \%$ salt reduction but did at a $33 \%$ salt reduction. Thus, consumers are very capable of detecting salt reductions in cheese, as was clearly shown by Drake et al. (2011), who reported that consumers noticed and identified salt reductions of as little as $12 \%$. Interestingly, whether consumed cold or hot as part of a pizza, the control, $25 \%$ reduced-salt, and $33 \%$ reduced-salt Mozzarella cheeses were similarly liked in both serving styles. We expected a higher liking score when the cheese was consumed as part of a pizza rather than cold as shreds. This finding probably reflects the increasing consumption of Mozzarella cheese as a snack in the form of string cheese, which has a higher salt content for maintaining firmness. In contrast, the liking scores for Cheddar cheese when served as a quesadilla were consistently higher ( 0.3 to 0.4 units) than when served as a cube of cheese. The lower liking scores for 6-mo-old Cheddar cheese than for 3-mo-old cheese indicate that the population of consumers sampled in this study had a preference for mild rather than aged cheeses. Likewise, when consumers tested the cheeses on pizza, cheeses with higher salt levels were liked better than cheeses with lower salt levels, but all cheeses were liked average or better (Figure 4).

When salt reduction in Mozzarella reached 50\%, average consumer liking decreased more rapidly for the cold cheese compared with cheese presented as a pizza. The lack of saltiness in the cheeses was probably ameliorated by salt in the pizza crust and the tomato sauce. Thus, even if the salt content of Mozzarella cheese could be lowered further, when it is used as an ingredient in multi-component foods, salt would need to be reduced in all components to obtain a sodium reduction in the whole food, which may further reduce consumer liking.

The appropriate level of sodium reduction for Mozzarella cheese may vary by application. For instance, string cheese normally has a higher salt level than shreds or blocks of Mozzarella cheese because it allows the cheese to retain a firmer texture for a longer period Therefore, making a $25 \%$ reduction in salt may produce a softer string cheese, even at similar moisture contents. For string cheese, this change in functionality 
would be unsuitable, whereas in cheese intended for pizza or baking, the change would be less important. There is promise in developing reduced-salt Cheddar and Mozzarella cheeses that are both functional and acceptable to consumers. Further research on reducedsodium cheeses focusing on specific applications would give more information on the ideal level of salt reduction at which acceptability is maintained. Moreover, characterizing proteolysis-induced changes in cheeses made with different starter bacteria over age would provide valuable information on the effect of salt on proteolysis at constant moisture and $\mathrm{pH}$. Methods to consistently produce acceptable reduced-salt Cheddar and Mozzarella cheeses with specific moisture and $\mathrm{pH}$ targets on the industrial scale are also necessary.

\section{CONCLUSIONS}

Cheddar and low-moisture, part-skim Mozzarella cheeses were each manufactured at total salt levels of $0.7,0.9,1.2,1.35$, and $1.8 \%$, representing salt reductions of $60,50,33$, and $25 \%$, respectively, while maintaining similar moisture and $\mathrm{pH}$. Salt content had a relatively minor influence on textural properties of Cheddar or on melting and stretch of Mozzarella cheese compared with storage time. For Mozzarella, reducing salt by up to $50 \%$ increased melting and slightly decreased stretch, and a $60 \%$ reduction in salt restricted melting. Consumer liking scores decreased with salt reduction for both cheeses when served individually or as part of a quesadilla or pizza, with liking differences noted by consumers at $33 \%$ salt reduction. At $50 \%$ salt reduction, all cheeses scored in the "liked slightly" range on the hedonic scale. On the other hand, at $60 \%$ salt reduction, liking decreased to the "neither liked nor disliked" range for Cheddar cubes and Mozzarella shreds, but was still "liked slightly" when Mozzarella cheese was served on pizza or mild Cheddar was served in a quesadilla. Even at comparable total salt levels, Mozzarella and Cheddar cheeses had different salty flavor scores, probably as a function of Mozzarella having a lower aqueous salt concentration because of its higher moisture content (48 vs. 37\% for Cheddar) and the contribution of other flavor attributes in Cheddar cheese. In the aged Cheddar cheese, other contributors to cheesy flavor such as brothy, buttery, sweet, and umami flavors decreased with salt content. Similar trends were apparent with Mozzarella cheese but not in the mild Cheddar.

\section{ACKNOWLEDGMENTS}

The study was accomplished as part of the cheese applications program of the Western Dairy Center
(Logan, UT) with funding by Dairy Management Inc., administered by the Dairy Research Institute (Rosemont, IL). The authors acknowledge the assistance of and thank Brian Pettee (formerly of Utah State University, Logan) and William R. McManus (formerly of Utah State University, Logan) for cheesemaking and performing proximate analysis.

\section{REFERENCES}

Agarwal, S., D. McCoy, W. Graves, P. D. Gerard, and S. Clark. 2011. Sodium content in retail Cheddar, Mozzarella, and process cheeses varies considerably in the United States. J. Dairy Sci. 94:16051615 .

Apostolopoulos, C., V. E. Bines, and R. J. Marshall. 1994. Effect of post-cheddaring manufacturing parameters on the meltability and free oil of Mozzarella cheese. Int. J. Dairy Technol. 47:84-87.

Bourne, M. C. 1978. Texture profile analysis. Food Technol. 32:62-66.

CDIC (Canadian Dairy Information Centre). 2013. Global and retail consumption. Accessed Aug. 1, 2013. http://www.dairyinfo.gc.ca/ index_e.php.

Doyle, M. E., and K. A. Glass. 2010. Sodium reduction and its effect on food safety, food quality, and human health. Comp. Rev. Food Sci. Food Safety 9:44-56.

Drake, S. L., K. Lopetcharat, and M. A. Drake. 2011. Salty taste in dairy foods: Can we reduce the salt? J. Dairy Sci. 94:636-645.

Euston, S. R., I. Piska, H. Wium, and K. B. Qvist. 2002. Controlling the structure and rheological properties of model cheese systems. Aust. J. Dairy Technol. 57:145-152.

Fife, R. L., D. J. McMahon, and C. J. Oberg. 2002. Test for measuring the stretchability of melted cheese. J. Dairy Sci. 85:3539-3545.

Fox, P. F., P. L. H. McSweeney, T. M. Cogan, and T. P. Guinee. 2000. Cheese rheology and texture. Pages 305-308 in Fundamentals of Cheese Science. Aspen Publishers, Gaithersburg, MD.

Grummer, J., and T. C. Schoenfuss. 2011. Determining salt concentrations for equivalent water activity in reduced-sodium cheese by use of a model system. J. Dairy Sci. 94:4360-4365.

Guinee, T. P. 2004. Salting and the role of salt in cheese. Int. J. Dairy Technol. 57:99-109.

Guinee, T. P., and P. F. Fox. 2004. Salt in cheese: Physical, chemical and biological aspects. Pages 207-259 in Cheese: Chemistry, Physics and Microbiology. Vol. 1. P. F. Fox, P. L. H. McSweeney, T. M. Cogan, and T. P. Guinee, ed. Academic Press, San Diego, CA.

He, F. J., and G. A. MacGregor. 2010. Reducing population salt intake worldwide: From evidence to implementation. Prog. Cardiovasc. Dis. $52: 363-382$.

Health Canada. 2010. Dietary Reference Intakes Tables. Accessed Aug. 1, 2013. http://www.hc-sc.gc.ca/fn-an/nutrition/reference/ table/index-eng.php.

Kindstedt, P. S., J. K. Rippe, and C. M. Duthie. 1989. Measurement of Mozzarella cheese melting properties by helical viscometry. J. Dairy Sci. 72:3117-3122.

Kuo, M. I., Y. C. Wang, S. Gunasekaran, and N. F. Olson. 2001. Effect of heat treatments on the meltability of cheeses. J. Dairy Sci. 84:1937-1943.

Lang, F. 2007. Mechanisms and significance of cell volume regulation. J. Am. Coll. Nutr. 26(Suppl.):613S-623S.

Liem, D. G., F. Miremadi, and R. S. Keast. 2011. Reducing sodium in foods: The effect on flavor. Nutrients 3:694-711.

Lindsay, R. C., S. M. Hargett, and C. S. Bush. 1982. Effect of sodium/ potassium (1:1) chloride and low sodium chloride concentrations on quality of Cheddar cheese. J. Dairy Sci. 65:360-370.

Martini, S., J. E. Thurgood, C. Brothersen, R. Ward, and D. J. McMahon. 2009. Fortification of reduced-fat Cheddar cheese with n-3 fatty acids: Effect on off-flavor generation. J. Dairy Sci. 92:18761884 .

McMahon, D. J., and C. J. Oberg. 2011. Cheese: Pasta-filata cheeses: Low-moisture part-skim Mozzarella (Pizza cheese). Pages 737-744 in Encyclopedia of Dairy Sciences. 2nd ed. Vol. 1. J. W. Fuquay, P. 
F. Fox, and P. L. H. McSweeney, ed. Academic Press, San Diego, CA.

Møller, K. K., F. P. Rattray, W. L. Bredie, E. Hoier, and Y. Ardo. 2013. Physicochemical and sensory characterization of Cheddar cheese with variable $\mathrm{NaCl}$ levels and equal moisture content. J. Dairy Sci. 96:1953-1971.

Moyes, B. L. 2003. Correlation between the USU stretch test and the pizza fork test. MS Thesis. Utah State University, Logan.

Mulder, H. 1952. Taste and flavour forming substances in cheese Neth. Milk Dairy J. 6:157-167.

NHMRC (National Health and Medical Research Council). 2006. Nutrient reference values for Australia and New Zealand including recommended dietary intakes. NHMRC, Canberra, Australia.

Oommen, B. S., D. J. McMahon, C. J. Oberg, J. R. Broadbent, and M. Strickland. 2002. Proteolytic specificity of Lactobacillus delbrueckii subsp. bulgaricus influences functional properties of Mozzarella cheese. J. Dairy Sci. 85:2750-2758.

Paulson, B. M., D. J. McMahon, and C. J. Oberg. 1998. Influence of sodium chloride on appearance, functionality, and protein arrangements in nonfat Mozzarella cheese. J. Dairy Sci. 81:2053-2064.

Richardson, G. H., ed.1985. Chemical and physical methods. Pages 327-404 in Standard Methods for the Examination of Dairy Products. 15th ed. American Public Health Association, Washington, DC.
Schroeder, C. L., F. W. Bodyfelt, C. J. Wyatt, and M. R. McDaniel. 1988. Reduction of sodium chloride in Cheddar cheese: Effect on sensory, microbiological, and chemical properties. J. Dairy Sci. 71:2010-2020.

Shrestha, S., J. A. Grieder, D. J. McMahon, and B. A. Nummer. 2011. Survival of Listeria monocytogenes introduced as a post-aging contaminant during storage of low-salt Cheddar cheese at 4, 10, and $21^{\circ} \mathrm{C}$. J. Dairy Sci. 94:4329-4335.

USDA. 2010. Dietary Guidelines for Americans, 2010. 7th ed. USDA and US Department of Health and Human Services, Washington, DC.

Wang, Y. C., K. Muthukumarappan, M. M. Ak, and S. Gunasekaran. 1998. A device for evaluating melt/flow characteristics of cheeses. J. Texture Stud. 29:43-55.

WHO. 2013. WHO issues new guidance on dietary salt and potassium. Cent. Eur. J. Public Health 21:16.

Wyness, L. A., J. L. Butriss, and S. A. Stanner. 2012. Reducing the population's sodium intake: The UK Food Standards Agency's salt reduction programme. Public Health Nutr. 15:254-261.

Xie, Y., L. S. Chou, A. Cutler, and B. Weimer. 2004. DNA Macroarray profiling of Lactococcus lactis subsp. lactis IL1403 gene expression during environmental stresses. Appl. Environ. Microbiol. 70:6738-6747. 